\title{
Efficacy of Low Level Laser Therapy in Oral Mucositis
}

\author{
Graça Maria Lopes Mattos ${ }^{1}$, Cayara Mattos Costa $^{2}$ and Clélea de Oliveira Calvet ${ }^{3 *}$ \\ ${ }^{1}$ CEUMA University, Brazil \\ ${ }^{2}$ Federal University of Maranhão, Brazil \\ ${ }^{3}$ Integrated Clinic Hospital, Brazil
}

Submission: November 02, 2018; Published: November 30, 2018

*Corresponding author: Clélea de Oliveira Calvet, Integrated Clinic Hospital, Maranhão, Brazil

\begin{abstract}
Patients submitted to radiotherapy or chemotherapy induced antineoplastic therapy have as their sequel oral mucositis, which is the main complication arising from the treatment. Laser therapy is a modality that has grown in recent years, with evidences of significant improvements in the prevention and treatment of oral mucositis. This study aims to show the benefits of low-level laser therapy application in patients submitted to antineoplastic therapy and present oral mucositis by means of an integrative literature review on the use of low-level laser to prevent and treat the lesion. A literature review was conducted with seven publications in Portuguese and English in PubMed and SciELO databases, from 2008 to 2018 and a summary table was prepared. It was observed that low-level laser therapy is an effective tool in the prevention and treatment of oral mucositis in cancer patients, bringing benefits such as: reduction of pain and severity of the lesion and anti-inflammatory, analgesic and healing effects.
\end{abstract}

Keywords: Laser Therapy; Oral Mucositides; Cancer patients

Abbreviations: OM: Oral Mucositis; LLLT : Low level Laser Therapy

\section{Introduction}

Through radiotherapy or chemotherapy, the antineoplastic treatment can cause cellular damage to the oral epithelium and salivary glands, as well as changing its functions and causing lesions, such as oral mucositis [1].

Oral Mucositis (OM) is an inflammation and ulceration of the oral mucosa, which becomes swollen and erythematous and may lead to the formation of large ulcers covered by pseudomembrane. This lesion is extremely painful and causes discomfort, dysphagia and systemic weakness, as well as being the most common cause of pain in the mouth in cancer patients [2-4].

Due to difficult feeding and speech, the ulcerations resulting from OM can increase the risk of local and systemic infection and can compromise oral function and interfere with antineoplastic treatment. It also may increase hospitalization stays time and influence the nutritional status of the patients. Lesions appear around 7 to 10 days after chemotherapy and generally from the second week of radiotherapy[3,5,6].

Some chemotherapy drugs are used alone or associated with radiotherapy in the hospital scope are responsible for the appearance of OM lesions, because they act mainly on tumor cells and affect the tissues of oral mucosa that result from immunosuppression. And due to the great sensitivity of the oral tissues and toxic effects of the chemotherapy drugs, lesions in oral cavity are the most common arise from chemotherapy [3].
And 5-fluorouracil, methotrexate, melafalan, cyclophosphamide, etoposide, mitoxantrane and cytarabine are the most common chemotherapy drugs [6,7]. Amoung these drugs, 5-fluorouracil, methotrexate and cyclophosphamide are the most related to the appearance of $\mathrm{OM}[3,6]$ in patients undergoing antineoplastic treatment.

The main clinical diagnosis of the severity of the $\mathrm{OM}$ is indicated by World Health Organization in scales varying from grade 0 to grade 4 , respectively: normal mucosa; erythematous mucosa; ulcer involvement and difficulty in solid feeding; presence of extensive ulcer and feeding of liquid consistency [8]. In 2014, the Multinational Association of Support Care in Cancer/International Society of Oral Oncology (MASCC/ISOO) has recommended low-level laser therapy because of its benefits as a form of OM prevention in patients who has received hematopoietic stem cells [9].

The photodynamic laser therapy, more specifically low-level laser therapy (LLLT), has been used in prevention and treatment of OM in recent years [10-12].The application of LLLT on OM has biological effects through photophysical and biochemical processes, increasing the cellular metabolism by stimulating mitochondrial activity. The result is an anti-inflammatory, analgesic and cicatrizator effect of lesions in the mucos [13] and collagen and elastin production, contraction of the wound and acceleration of healing, keeping the integrity of the mucosa [1]. 
A systematic review and meta-analysis [14] has showed a strong association in the treatment of $\mathrm{OM}$ by low-level red and infrared laser therapy, which had the potential to partially suppress the development of the OM induced by antineoplastic therapy and significantly reduced pain, severity of the lesion and duration of symptoms. Although laser therapy is demonstrating a considerable level of efficacy in reducing the grade of $\mathrm{OM}$ in patients undergoing antineoplastic therapy $[12,15,16]$ there are still no established protocols for the treatment of OM in cancer patients [17]. Nevertheless, studies have suggested that laser therapy could be used as a form of prevention and treatment of the OM lesions induced by the treatment of cancer $[13,18,19]$.

That way, Bensadoun and Nair [19] proved that there are consistent and favourable evidences to LLLT, as long as from

Table 1: Summary of articles included in this review. an ideal dose, and present as an accessible possibility for the tratment of $\mathrm{OM}$ induced by antineoplastic therapy. The authors still revealed that there is a possibility of LLLT become a part of the regular oral care in treatment of cancer. Thus, this study aims to show the benefits of the application of LLLT in cancer patients that present $\mathrm{OM}$, through an integrative review of literature about the use of this laser as an preventive measure and OM treatment.

\section{Materials and Methods}

The integrative review is a descriptive research method where it can search, critically evaluate and synthesize the available evidences about the theme, in order to show the current knowledge of the subject investigated, to intervene effectively in health care and to reduce costs, to identify gaps directed to the development of future research [20].

\begin{tabular}{|c|c|c|c|c|}
\hline No & Authors & Title & Objective & Results \\
\hline 1 & $\begin{array}{l}\text { Khouri et al. } \\
\qquad[18]\end{array}$ & $\begin{array}{l}\text { Use of therapeutic } \\
\text { laser for prevention } \\
\text { and treatment of oral } \\
\text { mucositis }\end{array}$ & $\begin{array}{l}\text { This study aimed to compare the } \\
\text { frequency and the Evolution of oral } \\
\text { mucositis among patients submitted } \\
\text { to therapeutic laser and conventional } \\
\text { therapy. }\end{array}$ & $\begin{array}{c}\text { There was a reduction in frequency and severity of oral } \\
\text { mucositis with the use of laser. The results suggested } \\
\text { that the therapeutic laser could be used in both cases } \\
\text { as a new form of prevention and treatment of oral } \\
\text { mucositis. }\end{array}$ \\
\hline 2 & Bjordal et al. & $\begin{array}{l}\text { A systematic review } \\
\text { and meta-analysis of } \\
\text { the effect of low-level } \\
\text { laser therapy in cancer } \\
\text { therapy-induced oral } \\
\text { mucositis. }\end{array}$ & $\begin{array}{l}\text { This study aimed to review the } \\
\text { effects of low-level laser therapy in } \\
\text { the prevention and treatment of oral } \\
\text { mucositis induced by antineoplastic } \\
\text { therapy. }\end{array}$ & $\begin{array}{c}\text { There are consistent evidences that low-level red } \\
\text { and infrared laser therapy may partially inhibit } \\
\text { the development of oral mucositis induced by } \\
\text { antineoplastic therapy, as well as significantly reduce } \\
\text { the pain, severity and duration of the lesion symptoms } \\
\text { caused by oral mucositis. }\end{array}$ \\
\hline 3 & $\begin{array}{l}\text { Bensadoun Nair } \\
\text { [19] }\end{array}$ & $\begin{array}{l}\text { Low-level laser therapy } \\
\text { in the prevention and } \\
\text { treatment of cancer } \\
\text { therapy-induced } \\
\text { mucositis: } 2012 \text { state } \\
\text { of the art based on } \\
\text { literature review and } \\
\text { meta-analysis. }\end{array}$ & $\begin{array}{l}\text { This study aimed to discuss the } \\
\text { promising state of low-level } \\
\text { laser therapy for preventive and } \\
\text { treatment of oral mucositis induced } \\
\text { antineoplastic therapy. }\end{array}$ & $\begin{array}{l}\text { No adverse effects of low-level laser therapy were } \\
\text { reported. Thus, low-level red and infrared laser } \\
\text { therapy are recommended to prevention and } \\
\text { treatment of oral mucositis. }\end{array}$ \\
\hline 4 & $\begin{array}{l}\text { Migliorati et al., } \\
\text { [19] }\end{array}$ & $\begin{array}{l}\text { Systematic review } \\
\text { of laser and other } \\
\text { light therapy for the } \\
\text { management of oral } \\
\text { mucositis in cancer } \\
\text { patients. }\end{array}$ & $\begin{array}{l}\text { This study aimed to review the } \\
\text { available literature and to define } \\
\text { clinical practices for the use of laser } \\
\text { and other photodynamic therapies } \\
\text { for the prevention and treatment of } \\
\text { oral mucositis }\end{array}$ & $\begin{array}{l}\text { Two new guidelines were created in favor of increasing } \\
\text { evidences of the efficiency of low-level laser therapy. }\end{array}$ \\
\hline 5 & $\begin{array}{l}\text { Figueiredo et } \\
\text { al., [13] }\end{array}$ & $\begin{array}{l}\text { Laser therapy in oral } \\
\text { mucositis control: a } \\
\text { meta-analysis. }\end{array}$ & $\begin{array}{l}\text { This study aimed to conduct a } \\
\text { systematic review and meta-analysis } \\
\text { of the effectiveness of laser therapy } \\
\text { in the prevention of oral mucositis in } \\
\text { patients undergoing oncotherapy. }\end{array}$ & $\begin{array}{c}\text { Twelve studies were included. The meta-analysis } \\
\text { of seven of these concluded that laser therapy in } \\
\text { patients undergoing oncotherapy is about nine times } \\
\text { more effective in the prevention of oral mucositis } \\
\text { grade greater than } 3 \text { than in patients without laser } \\
\text { treatment. }\end{array}$ \\
\hline 6 & Oberoi et al. & $\begin{array}{l}\text { Effect of prophylactic } \\
\text { low-level laser therapy } \\
\text { on oral mucositis: a } \\
\text { systematic review and } \\
\text { meta-analysis. }\end{array}$ & $\begin{array}{l}\text { This study aimed to determine } \\
\text { whether prophylactic low-level laser } \\
\text { therapy reduces the risk of severe } \\
\text { mucositis as compared to placebo or } \\
\text { no therapy. }\end{array}$ & $\begin{array}{l}\text { Eighteen randomized clinical trials showed risk } \\
\text { reduction of severe mucositis, as well as reduced } \\
\text { outcomes when compared with placebo or no therapy. }\end{array}$ \\
\hline 7 & HE et al., 2018 & $\begin{array}{l}\text { A systematic review } \\
\text { and meta-analysis of } \\
\text { the effect of low-level } \\
\text { laser therapy (LLLT) } \\
\text { on chemotherapy- } \\
\text { induced oral mucositis } \\
\text { in pediatric and young } \\
\text { patients. }\end{array}$ & $\begin{array}{c}\text { This study aims to synthesize the } \\
\text { available clinical evidences on the } \\
\text { effects of low-level laser therapy } \\
\text { in the prevention and treatment } \\
\text { of chemotherapy-induced oral } \\
\text { mucositis. }\end{array}$ & $\begin{array}{l}\text { Prophylactic low-level laser therapy reduces mucositis } \\
\text { and severe mucositis and decreases the average } \\
\text { severity of oral mucositis in pediatric and young } \\
\text { patients with cancer, as well as reduces the average } \\
\text { severity of oral mucositis and oral pain. }\end{array}$ \\
\hline
\end{tabular}


It should be emphasized that the integrative review contributes to the process of research and analysis of the results, aiming to increase of a specif topic based in other social studies already published. This methodology of integrative review of the literature allows the accomplishment of successful analyzes on the data collection and information, besides the diagnosis and presentation of the results of the beginning of the study. A literature review of the publications in Portuguese and English was conducted in PubMed and SciELO databases, from 2010 to 2018, using descriptors according to DeCs (Bireme Health Descriptors) related to: laser, oral mucositis and cancer patients.

After the identification of 10 (ten) articles, an exploratory reading of the abstracts was conducted in order to verify if the article fit the theme. Then, 7 (seven) articles were selected for analysis and subsequent discussion.It was excluded articles that did not have the inclusion criteria, those that presented duplication amoung databases and articles that after detailed reading did not have the objective proposed in this review.

A table was prepared with the purpose of synthesizing and comparing the obtained data. In relation to the ethical aspects, there was the concern to register the necessary information to the identification of the authorship of the investigated articles and the care of changing nothing about the available information in the articles analyzed.In the last decades, due the evolution of treatments in cancer patients and with the research for better conditions to them, the photodynamic therapy, more specifically LLLT emerged as na ally with the prevention and treatment of OM induced by antineoplastic treatment [10-12].

Khouri et al.[18] conducted a study in Ribeirão Preto, Brazil, that has showed significant improvements through the use of laser therapy in prevention and treatment of $\mathrm{OM}$. The laser therapy provided pain relief, inflammation control, maintenance of the integrity of oral mucosa, tissue repair and patient comfort. n 2012, a systematic review and meta-analysis [14] confirmed the information from Khouri study [18]. This systematic review evaluated the interaction between laser therapy and $\mathrm{OM}$ and found strong evidences regarding the efficacy of low-level red and infrared laser therapy in the development of OM induced by antineoplastic therapy. The study also found that the laser therapy would have significantly reduced the pain, severity and duration of the lesions symptoms.

Other systematic review [17] compared light and laser therapies in the treatment of $\mathrm{OM}$ in cancer patients. They concluded that the evidences were favorable to laser therapy and that the studies about the efficacy of laser therapy were raising. That way, Figueiredo et al.[13] pointed significant prophylatic effects on OM with a degree greater than three submitted to laser therapy.

Previous studies $[13,14,18]$ were confirmed by a systematic revie [12] that revealed LLLT reduced the severity of lesions and pain in cancer patients when laser was applied as a prophylatic measure. And due the care about possible adverse effects of laser therapy, Bensadoun and Nair [19] reviewed the literature and conclued that no adverse effects have been reported from the use of LLLT in prevention and treatment of OM induced by antineoplastic therapy.

In addition, Bensadoun and Nair [19] revealed there are moderate to strong evidences in favor of the application of lowlevel laser in ideal doses as an cheap and eficiente alternative for OM induced by antineoplastic therapy. The authors also predicted that laser therapy would become a part of the oral care routine in cancer.

Migliorati et al. corroborated with Bensadoun and Nair [19] and conclued that the application of LLLT had the potential to become routine of care practice in combat OM. That way, in 2014 the Multinational Association of Support Care in Cancer/ International Society of Oral Oncology (MASCC/ISOO) has recommended LLLT [9] in its guide as an intervention in OM. The guide is based on strong evidences that supported the treatments in situations indicated by the guide: LLLT (wavelength up to $650 \mathrm{~nm}$, power of $40 \mathrm{~mW}$ and a tissue energy of $2 \mathrm{~J} / \mathrm{cm}^{2}$ ) in the prevention of $\mathrm{OM}$ in patients who transplanted hematopoietic cells after conditioning with high dose of chemotherapy, with or without total body irradiation. And with reduced evidences, the guide recommended LLLT (wavelength about $632.8 \mathrm{~nm}$ ) in the prevention of $\mathrm{OM}$ in patients submitted to radiotherapy without concomitant chemotherapy for head and neck cancer.

Bensadoun e Nair [19] has recommended the treatment with LLLT should be repeated every day, every other day or at least three times a week until the wound heals. Nevertheless, although the laser therapy is demonstrating a reduction in $\mathrm{OM}$ in patients undergoing antineoplastic therapy $[12,15,16]$, a protocol to be followed in the treatment of OM in cancer patients has not yet been established [17].

Finally, a systematic review [21] analyzed the effects of LLLT in OM induced by antineoplastic theray in pediatric and young patients. The findings corroborate with other studies in adults $[12-14,18]$ in order to reduce pain and severity of OM, providing relief of symptoms and being na excelente option for prevention and treatment of OM.

\section{Conclusion}

Several systematic reviews have proved by strong associations the efficacy of laser therapy in treatment and prevention of $\mathrm{OM}$ $[12,14,17,21]$. In addition, all articles consulted have presented favorable results for the use of laser therapy in prevention and treatment of OM induced by antineoplastic treatment.Thus, the laser therapy is a promissing and effective tool for prevention and treatment of $\mathrm{OM}$ in cancer patients and it brings benefits such as reduction of pain and severity of the lesion and anti-inflammatory, analgesic and healing effects.It is believed that soon laser therapy will be a mandatory part of the care protocol for OM prevention and treatment, although protocols established in the researched literature have not been found. 


\section{References}

1. Reolon LZ, Rigo L, Conto F, Larissa Cunha CE (2017) Impact of laser therapy on quality of life of câncer patients with oral mucositis. Rev. Odontol UNESP 46(1): 19-27.

2. Volpato LER, Silva TC, Oliveira TM, Sakai VT, Machado MAAM. (2007) Mucosite bucal rádio e quimioinduzida. Rev Bras Otorrinolaringol 73(4): 5620-5628.

3. Fernando LH, Tinoco BEM, Teixeira HGC, Falabella MEV, Neuza MSPA (2010) Manifestações bucais em pacientes submetidos à quimioterapia. Ciência \& Saúde Coletiva Rio de Janeiro 15(1): 1085-1094

4. Caldas JA, Barbosa A, Teti IM, França MLMS, Paegle ACRO, et al(2015) Alterações Bucais Em Pacientes Submetidos Ao Tratamento Quimioterápico De Câncer Na Rede Pública De Recife-Pe. Ciênc bio saúde 2(2): 37-46.

5. Köstler WJ, Hejna M, Wenzel C, Zielinski CC (2001) Oral mucositis complicating chemotherapy and/or radiotherapy: options for prevention and treatment. CA Cancer J Clin 51(5): 290-315.

6. Marina C, Luiz A V S Junior, Manoela D M, Paulo Sérgio da S S (2018) Protocolos quimioterápicos e incidência de mucosite bucal. Revisão Integrativa. Einstein (São Paulo) 16(1): 1-9.

7. sociedade Brasileira De Transplante De Medula Óssea (2012) Diretrizes da Sociedade Brasileira de Transplante de Medula Óssea. Rio de Janeiro.

8. Carvalho PA, Jaguar GC, Pellizzon AC, Prado JD, Lopes RN, et al. (2011) Evaluation of low-level laser therapy in the prevention and treatment of radiation-induced mucositis: A double-blind randomized study in head and neck cancer patients. Oral Oncol 47(12): 1176-1181.

9. Lalla RV, Bowen J, Barasch A, Elting L, Epstein J et al. (2014) MASCC/ ISOO Clinical practice guidelines for the management of mucositis secondary to cancer therapy. Cancer 120(10): 1453-1461.

10. Lino MD, Carvalho FB, Oliveira LR, Magalhães EB, Pinheiro AL et al. (2011) Laser phototherapy as a treatment for radiotherapy-induced oral mucositis. Braz Dent J 22(2): 162-165.

11. Arora H, Pai KM, Maiya A, Vidyasagar MS, Rajeev A (2008) Efficacy of He-Ne Laser in the prevention and treatment of radiotherapy-induced oral mucositis in oral câncer patients. Oral Surgery Oral Med Oral Pathol Oral Radiol Endodontology 5(2): 180-186.

12. Sapna O, Gabriele ZN, Joseph B, Nathaniel S T, Lillian S (2014) Effect of prophylatic low level laser terapy on oral mucositis: a systematic review and meta-analisys. Plos One 9(9): e107418.

13. Figueiredo ALP, Lins L, Cattony AC, Falcão AFP (2013) Laser terapia no controle da mucosite oral: um estudo de metanálise. Rev Assoc Med Bras 59(5): 467-474.

14. Bjordal JM, Bensadoun RJ, Tunèr J, Frigo L, Gjerde K et al.(2011) A systematic review with meta-analysis of the effecr of low-level laser therapy (LLLT) in cancer therapy-induced oral mucositis. Support Care Cancer 19(8):1069-1077.

15. Rampini MP, Ferreira SEM, Ferreira CG, Antunes HS (2009) Utilização da terapia com laser de baixa potência para prevenção de mucosite oral: revisão de literatura. Revista Brasileira de Cancerologia 55(1): 59-68.

16. Flávia MG, Isabelle PG,Flávia F (2010) Prevenção e tratamento da mucosite oral. Rev. Enferm, Rio de Janeiro 18(1): 67-74.

17. Migliorati C, Hewson I, Lalla RV, Antunes HS, Estilo CL et al. (2013) Systematic review of laser and other light therapy for the management of oral mucositis in cancer patients. Support Care Cancer 21(1): 333341 .

18. Khouri VY, Stracdieri AB, Rodrigues MC, Moraes DA, Pieroni F, et al. (2009) Use of therapeutic laser for prevention and treatment of oral mucositis. Braz Dent J 20(3): 215-220.

19. Bensadoun RJ, Nair RG (2012) Low-level laser therapy in the prevention and treatment of cancer therapy-induced mucositis: 2012 state of the art based on literature review and meta-analysis. Curr Opin Oncol 24(4): 363-370.

20. Mendes KDS, Silveira RCCP, Galvão CM (2008) Revisão Integrativa: Método De Pesquisa Para A Incorporação De Evidências Na Saúde E Na Enfermagem. Texto Contexto Enferm Florianópolis 17(4): 758-764.

21. HE M, Zhang B, Shen N, WU N, SUN J (2018) A systematic review and meta-analysis of the effect of low-level laser therapy (LLLT) on chemotherapy-induced oral mucositis in pediatric and young patients. Eur J Pediatr 177(1): 7-17.

\section{Your next submission with Juniper Publishers will reach you the below assets}

- Quality Editorial service

- Swift Peer Review

- Reprints availability

- E-prints Service

- Manuscript Podcast for convenient understanding

- Global attainment for your research

- Manuscript accessibility in different formats

( Pdf, E-pub, Full Text, Audio)

- Unceasing customer service

\section{Track the below URL for one-step submission}

https://juniperpublishers.com/online-submission.php 